\title{
Higher Education Student Body Diversification as Glocal Practice ${ }^{1}$
}

\section{La Diversificación del Cuerpo Estudiantil en la Educación Superior como Práctica Glocal}

\author{
José Gerardo Alvarado
}

\author{
Virginia Polytechnic Institute and State University
}

JoGA1@aol.com

\begin{abstract}
Georg Simmel's assertion that strangeness organizes nearness and remoteness helps to understand how the social category of First Generation College Student (FGCS, first in the family to attend college) is used at a public university in the United States southwest. Membership Categorization Analysis (MCA) is applied to ethnographic data. Difference categories and devices morph into those of distance in an interaction where a recruitment convention substitutes for a handshake between a boy and some adults in the hallway of a student center. These changes imbricate with those found in the analysis of a student-persistence sequence of an educational marketing recruitment DVD. As evidence of glocal practice or the global impact of local contact gestures of student body diversification or massification policies directed at FGCSs (and others), they appear to coincide with distribution and recognition social justice projects that are inviting us to reach out across distances, short and long.
\end{abstract}

Keywords: First Generation College Student; Membership Categorization Analysis; Ethnography

\section{Resumen}

La afirmación de Georg Simmel que la extrañeza organiza la cercanía y la lejanía ayuda a entender cómo se utiliza la categoría social de estudiante universitario de primera generación (EUPG, primer integrante de la familia en la educación superior) en una universidad pública en el suroeste de Estados Unidos. El análisis de pertenencia categórica (MCA, Membership Categorazation Analysis) se aplica a datos etnográficos. Tanto unas categorías y unos dispositivos de diferencia se transforman en unos de distancia en una interacción donde una convención de reclutamiento se llega a sustituir por un apretón de manos entre un niño y algunos adultos en el pasillo de un centro estudiantil universitario. Estos mismos cambios se encuentran imbricados en el análisis de una secuencia de persistencia estudiantil en un DVD que fue producido por una institución de educación para atraer y reclutar a estudiantes. Como evidencia de unas prácticas glocales o del impacto global de unos gestos locales de contacto de unas políticas dirigidas hacia los EUPG (y otros) con la finalidad de la diversificación o la masificación del cuerpo estudiantil, éstas parecen coincidir con los proyectos de distribución y reconocimiento de la justicia social, mismos que se nos invitan a extendernos a través de distancias cortas y largas.

Palabras clave: Estudiante Universitario de Primera Generación; Análisis de Pertenencia Categórica (MCA, Membership Categorization Analysis); Etnografía

Children on their "potty break" scuttled up and down the hall of the student center at the university where I did the fieldwork for my dissertation (Alvarado, 2010). They had come to hear a Chicano author read some of his children stories and were now on their way back to their middle school. As I made my way

\footnotetext{
${ }^{1}$ Paper originally presented at the 82nd Annual Convention of the Southern States Communication Association, April 11-15, 2012, San Antonio, TX. Correspondence concerning this paper should be addressed to José G. Alvarado, $\mathrm{CHCl}$, Department of Computer Science, College of Engineering, 2202 Kraft Drive, Virginia Polytechnic Institute and State University, Blacksburg, VA 24060. Electronic mail can be sent to jgalvara@vt.edu.
} 
through the children I saw my field consultant standing in the middle of the hallway with other adults who were in business attire. As I approached and to the surprise of all of us, we heard the voice of a boy ask his teacher, "What do these people do?" My consultant made eye contact with the boy's teacher and then gently took him by the shoulder to point out one of the many pictures hanging on the wall. He told him the adults were relatives of the man who was being commemorated during Hispanic month. The boy was then introduced to the man's relatives and instead of a handshake, and after what seemed an eternity the man's widow asked him if he was going to study at this university.

This very specific interaction between a child and some adults in the hallway of a building at an institution of higher education (HE) provides evidence of university policies in action, of recruitment practices tied to events for persons from underrepresented populations. It shows what can happen when a university welcomes some young students from local schools to campus. This is a common practice for higher education institutions surrounded by neighborhoods composed of residents who have little to do with academia, as well as for those that by design become one more gated community surrounded by others. The data presented here comes from ethnographic fieldwork carried out over a ten month period at a public university in the United States southwest where a Hispanic male friend of mine who works as a counselor under the division of student affairs acted as my consultant or primary contact for the study. The objective of my collaborative institutional ethnographic work with him was to show how the social category of First Generation College Student (FGCS, first in the family to attend college) gets used at this university in day-to-day life. Along these lines, I was able to capture a number of experiences in my fieldbook, as well as a number of artifacts such as an educational marketing DVD that presents the experiences of FGCSs, the cover of an alumni bulletin on which a student appears with a sash as part of his academic regalia, and a grant application written by the directors of a FGCS program of the department of social work.

Georg Simmel's (1950) assertion that strangeness is what organizes nearness and remoteness offers a way to think about the distance traversed when a university opens its doors to persons who know little about academia due to their personal experience, and one that is duly captured by academic and administrative measures. Loukia Sarroub (2008) writes about literacy requirements and continually goes back and forth between immigrant refugees and the local low SES students who share the same high school remediation classes in the Midwest to explore glocality in education. She states that literacy practices "depend, in large part, on the socialization of individuals' identities in different contexts and places and on scholarly research mediated by political agendas" (p. 61). The concept of glocality might help us think about the higher education practices directed at FGCSs. In this sense, institutional glocal practices are the changes people from diverse backgrounds make when they interact with each other. Higher education, then, is a place where the global meets the local, a setting for "new interactions" where both international students and FGCSs go through what the education literature calls a transition to college (Deil-Amen \& López Turley, 2007; Jean, 2010; Kurotsuchi Inkelas, Daver, Vogt \& Brown Leonard, 2007). This offers evidence of an overlap that could be considered glocal, in terms of the bridging identity work needed to ensure academic success for individuals who have chosen to take on the academic life where the higher education site functions both as a global and local portal passage from the margins of society.

I argue that adaptations to newness, commonly understood in terms of institutions receiving students from abroad also occur when institutions make accommodations for students who come from locally underrepresented populations. The higher education socialization processes for the former often share 
similarities with practices made to insure academic success for the latter. The objective here is not to provide a point-by-point comparative between practices with international students and local FGCSs who may also pertain to underrepresented populations. Instead, the focus is on institutional practices associated with FGCSs, the research done on/with them, as well as what we can glean from some of the data gathered throughout my institutional ethnography research in the halls of academia.

The idea of glocal practices in higher education, as things done to improve the academic success rate of an ever-diversifying population, offers a chance to question how universal notions related to meritocracy function as educational norms. Higher education will need to be aware of the K-12 curriculum adaptations required to meet local educational requirements, to be able to serve a population where every one in five students will be an immigrant or the child of immigrants by 2020 in the United States (Suárez-Orozco, 2001). Glocality can help us think about the process in terms of a dialogue between students and institutions, ultimately answering to a world of academic consumers, which in turn is made up of each of us.

The characteristics and activities associated with FGCSs correspond to who they are as persons as well as to higher education scientific and institutional practices enacted on their behalf. There is scientific activity that adds to the density of the FGCS category that also points out the central role of the Traditional Student (TS) social category in higher education institutional practices aimed at increasing students' educational possibilities (Alvarado, 2010). Research that looks at the obstacles FGCSs face, the persistence they demonstrate, and at an extensive inventory of predictors related to their academic success are in turn utilized by institutions to develop policies and strategies. In the process the TS, as the quintessential basis for comparison offers a productive point of departure to reflect upon the practices of researchers and administrators. It helps us think about the procedures we enact to specify the variables of an object of study, of how we participate in the consolidation of categories we may consider extant or truly within our grasp as things that exist in and of themselves, while keeping in mind that there is no category that is beyond the influence of contextual practices enacted by ourselves and others.

The FGCS category is one among a variety of other categories that evoke the complex intersection of oppressions experienced by a group of persons who have chosen to enter the world of academia (Choy, 2001; Warburton, Bugarin \& Nuñez, 2001). Due in part to immigration, demographic changes in the United States show a decrease in the non-Hispanic White college population and an increase of minority and ethnic groups of first-generation (FG) status, a category that by itself tends to refer to students who are immigrants, whose parents tend to have little or no post-secondary academic experience, and who experience situations that expose them to language, integration, and low socioeconomic issues (Thomas \& Quinn, 2006). They are students who come from families that recently settled in the country, and they tend to be at risk in terms of academic performance and retention (Amelink, 2005). Similarly, research with students from a blue-collar background who were in college in the 1960s and 1970s found that they reported feeling alienated and inferior vis à vis the "real college students" (Hayes, 1999). They found paths to self-empowerment in the process of actively seeking help from key persons and groups in a process that involved risk-taking, rejection, reticence, reflection and resolve. The efforts of blue-collar students have resulted in degree attainment, much like the high persistence of FGs, despite both groups having lower grade point averages (GPAs) in comparison to their respective counterparts (not-blue-collar and non-FG). 
To be sure, while higher levels of academic preparation favor academic performance in college (D'Amico, 2004), academic success has also been related to an institution's ability to foster active and collaborative learning as well as encouraging positive interactions with faculty (Amelink, 2005). Along these lines, retention and course completion rates have been related to academic preparation and academic involvement although less prepared older students often have higher GPAs while females tend to have higher GPAs than males. And in terms of ethnic groups, African-Americans have higher attrition rates than Hispanics when both of these groups tend to have lower GPAs and arrive less prepared for college work than Asian students who are more likely to remain in school (Espanola, 2004).

These findings draw attention to institutions interested in meeting First Generation College Students' expectations and recognizing their needs, trying to communicate better with them throughout the complex processes of recruitment, admission and retention (Joyce, 1987). While Ronnie Nolan (2005) highlights the benefits of special academic programs, he notes that FGCSs attending a historically Black university (84.4\% African-American) were more likely to stay until graduation. These students spent less time socializing and had a higher expectation of transferring to another institution than non-FGCSs despite evidence that both groups report similar academic and social expectations (Murphy, 2006). The combination of personal resilience with campus life involvement makes these students capable of overcoming financial barriers, a lack of family support, lower academic preparedness, as well as the low levels of personal commitment and support they report.

Yet, the link between scientific work and administrative policies is submerged in research that focuses on factors related to social economic status, race, gender, language ability, and the trends found among immigrant students fitting the FG category appear to be significant for other groups. We can find broad mega-groupings, particularly in terms of the categories that are created through scientific and administrative practices to understand the problems of particular populations. Indeed, differences in generation (Stanfield, 1993), to include the millenial generation student (VanFossen, 2005) or the 1.5 generation student (Gulikers, Meredith \& Swartz, 2004), combined with gender or color (Kuriloff \& Reichert, 2003; Lee, 2004), or strictly limited to learning styles (Anderson, 1995) are some of the ways we are able to think about ourselves. Policies begin to be established, such as when education resources are considered in Congress in the case of attracting students to math and science (United States Government Printing Office, USGPO, 2000), and where debates are centered on questions of equity and excellence (Lederman, 2005; Scott, 1996; Suggs, 2005). Seen as practice, the density strength of each of the categories we focus on fluctuates throughout the range of efforts directed at increasing opportunities for specific sectors of the population.

Additionally, the idea of glocal practices in education, as things that are done to improve the academic success rate of an ever diversifying population offers a chance to question how universal notions related to meritocracy became the basis for educational norms, particularly in terms of the Traditional Student category on which many of these practices are based. Marcelo M. Suárez-Orozco (2001) links globalization, immigration, and education research that will be able to prepare students for the postnational knowledge-economies of the new millennium to point out that schools are perhaps the only portal to this new world of challenges and possibilities. Conflicting discourses around Widening Participation initiatives in the United Kingdom also show how the process of the massification of education is highly contested given that the freedom each university has to meet these goals tends to exacerbate the disparity between traditional and less established institutions (Stevenson, Clegg, \& Lefever, 2010). Glocality may help us think about these practices in terms of a continuing dialogue between students and 
institutions shaped by diversification concerns. That Hispanic Serving Institutions and Historically Black Colleges and Universities receive extra federal support simply for having a greater number of students from minority populations demonstrates only some of the many responses made to diversification concerns in the world of academic consumers/producers in the United States.

The data presented here come from an ethnomethodologically informed ethnography rooted in a social science perspective that is less interested in ironing out reality and more inclined at making its complexity intelligible (Alvarado \& Íñiguez-Rueda, 2009). By the same token, when I talk about glocal practices, I reserve the right to delve into the minutiae of interactions to see how they work and reveal the resulting significations of a constellation of categories used in them. Membership Categorization Analysis (MCA) is used because it is congruent with the dialogue between social redistribution and recognition approaches (Fraser \& Honneth, 2003; Freiberg \& Freebody, 2009) that are central to accomplishing student body diversification practices. MCA pertains to what Rogers Brubaker (2009) broadly considers the cognitive perspectives that attempt to elide groupism, preferring instead to unpack the means by which we sustain identity differences in racial, ethnic, or national terms. It details identification and categorization events (Brubaker \& Cooper, 2002), offering evidence that can help inform policies responding to important identity claims such as those found in the sociology of education literature that are part and parcel to the diversification we are constructing as we speak (David, 2009).

\section{Culling Through Data}

"Recruiting already!", percolated through the laughter we shared upon seeing the boy light up when he responded with a spirited "yes" to the question the commemorated Hispanic author's widow had asked. Recruitment accomplished, what was left for us to do was wait for the events of time to take their course. However, it was not long before he was back with his teacher and my consultant heard her tell him he had just met some important people. It is tempting to simply say this child is special, which means saying his inquisitive nature will surely benefit him in any path he takes. We can also pull back and study the interaction for all of the categories that were brought to bear to make the interaction performatively possible.

I wrote extensively at various points throughout my fieldbook about the interaction reflecting on how a recruiting convention was substituted for a handshake at that moment when my friend formally introduced the boy to the commemorated Hispanic author's family. The following is the first paragraph of the first notes I wrote.

We are on the 3rd Floor of the [student center], well this was actually on Friday, I had been hanging around with the children since I had not been able to go to the FGSO presentation at the [NAME] Center. It was at about 14h, a between time of 30 minutes, between moving from being with the children who were now being allowed a "potty break" before then going to be loaded up on the bus to go back to [name] Intermediate School. I didn't know why at the time, but a bunch of adults dressed in business attire were in the hallway, [my consultant] among them, and I made my transition from the world of [a children's story with a Spanish name] of [author] to the world of Distinguished Alumni Photos; the hallway with pictures (Extract 1, Fieldbook entry, 29 Oct. 2005). 
Membership Categorization Analysis (MCA) used to unpack ethnographic data captured in fieldnotes and the information contained in printed documents gathered throughout the course of fieldwork at a university charges the course for an ethnomethodologically informed ethnography. It has a particular way of treating the categories or identities as they emerge in the data, as evidence of practices in the sense that Moerman (in Antaki, 1998) means when he says, "the 'truth' or 'objective correctness' of an identification is never sufficient to explain its use" (p. 2). Practices are central to an ethnomethodologically informed ethnography approach, it takes social facts as the phenomena where the detailed description of practices is itself seen as a process of reflection on social interactions, as when ethnicity is couched in terms of a "situated practical accomplishment" (Hansen, 2005).

The words I chose allowed me to tell the ethnography. The words used to describe persons, places, events, and things could be seen as abstractions but they can also be many other things, since what is being uncovered is consists of a variety of categories. Some of these categories might be new to those not familiar with the field, giving us the possibility to problematize my socialization process. In this sense, fieldnotes are reflections on the categories that emerge throughout the fieldwork. At the same time, who the people are, or more precisely, the exercise of writing about a boy may have the tendency of distancing us from the interaction that is being captured. In this case, attempts at telling who he is needs to be done in conjunction with the narrative that alludes to him. While he may be a son, a brother, a Roman Catholic, or even a soccer player, what is made relevant in the fieldnote narrative, as my recollection of an interaction that took place in the hallway of a building, is that:

"He was a 5th or 6th grader, thin and had dark skin. He spoke English well and when he stopped to ask that question out loud" (Extract 2, Fieldbook entry, 29 Oct. 2005).

I will now use MCA to explore the categories in Extract 1 and situate them within the newness criteria of university glocal practices. The extract functions as an introduction in that it sets the stage in terms of location and time. It also describes the setting in terms of movement, first in terms of a space and then in terms of an event. It begins to relate the story about something that happens on a Friday and by coupling the date with the place we can talk about a day-at-the-university membership categorization device (MCD). "A device is then a collection plus rules of application" (Sacks, in Hester \& Eglin, 1997, p. 4), i.e., categories having something in common, for example 'clarinetist' and 'first violin' pertaining to the MCD of orchestra.

I say I am with 'children' while stating that I had the option of being with 'FGSO presentation participants' in another building. In the process of the description, a university-activities device gets established to which both the 'activity for children' and the 'FGSO presentation' pertain. Although an elaboration of the FGSO acronym is not offered in the fieldnote, that fact that it is included makes it possible to say that the intended reader would be able to recognize it as standing for the First Generation Student Organization at this university. The word "student" places it under a college-student-activities device, an 'FGSO presentation' that took place at another location. What is relevant, however, is that the fieldnote is simultaneously referring to two different events that took place at the same time in two different places, where one was for children while the other one was for college students. In terms of the buildings where these activities took place, their names are mentioned but their relevance has more to do with pertaining to a university-building device. What is significant is that of the two, a culturally competent community member would be able to recognize that the student center is named after a prominent politician who was from the state where I did the ethnography. 
The next reference is specific to time, where " $14 \mathrm{~h}$ " is in the 'afternoon' while a specific reference to a "between time of 30 minutes" adds the category of a 'break' to a time device that has been put into play. The time references correspond to my movement and that of the children. In turn, the movement allows for a description of 'children' in this space and at a time that is described as a "potty break". Subsequently, the 'children's break' is connected to what they will be doing next, that is, getting "on the bus to go back to" their school. The fact that they are returning to another place makes them visitors or 'children on a field trip' who will be returning to their "Intermediate school". Here again, the name of their school is included in the text, suggesting the relevance of a building-name device.

The next phrase, "I didn't know why at the time", triggers a transition in the fieldnote narrative and the new focus is on "a bunch of adults in business attire" who are "in the hallway". We might stop to consider that 'children on a field trip' dress differently than 'adults at an event' and begin to list characteristics for each of the categories. What is relevant, however, is the movement that is being traced as we are taken from an 'event for children' to another space. With the use of the word "bunch" to describe some type of disorganization, it becomes possible to say that we are being taken to a break time for adults as well as for the children. In terms of the space and as the text continues, we find adults and children sharing a hallway, a place that has doors that lead to "potty" rooms as well as a 'hallway with pictures' that has "Distinguished Alumni Photos". If we stop to think about the name of the building and the fact that it has a hallway with distinguished alumni photos, the student center is a place where a commemorative-function device begins to gain purchase since it is a naming and showcasing place. The student center's name commemorates a prominent politician and the photographs in the hallway of the building commemorate 'alumni'. Although not explicated in the text, a culturally competent member of the community would recognize that the politician for whom the student center is named was also a university alumnus. In the following section I will explore how the question the child asks his teacher gets taken up into a hospitality interaction.

\section{Glocal Interactions}

Up to this point, the analysis of Extract 1 reveals how some categories of difference morphed into others of distance, and how some activities devices got mapped onto others of commemoration. I will start from again from the introduction to see how these changes can be seen as glocal practice. The variety of devices introduced at the beginning set the scene in terms of time and location, where the relevance of building naming evokes a commemorative-function device. A university-activities device allows for a list of categories to refer to what some children and adults are doing while a particular presentation is mentioned that corresponds to a college-student-activities device. Although references to myself in this paragraph place me as a fieldnote writer and an ethnographer, it is these same categories that allow me to be an adult attending a number of activities.

To situate the categories and devices in glocal practice terms, we first need to establish some rules of newness to think about the interactions between people from diverse backgrounds. Georg Simmel's (1950) assertion that strangeness is what organizes nearness and remoteness helps us think about the link between things local and global. MCA organizes categories according to rules based on shared characteristics and activities. In this sense, a commemorative-function device can include building naming and the event covered in the extract (we commemorate people who have passed on). It can also be seen 
as a convergence event for other categories that emerged from the other ethnography's data sets, in turn showing their mutual imbrication.

\section{A recruitment DVD}

It was my consultant's news about an FGCS recruitment DVD he had produced that lead me to choose my dissertation topic: university policies and their identity work when this social category is put into play in day-to-day institutional practices. Through his work as a counselor at the institution he was able to gather the resources to professionally edit a DVD that presents a focus group interview. It consists of two parts, an introductory narrative presented by a Hispanic female who identifies herself as a First Generation Graduate. The second part is the interview itself where of the five female student participants, one is White, one is Black, and three are Hispanic. Of the two males, one is Black and the other Hispanic. With this, the Hispanic ethnicity my consultant and I share begins to gain purchase, and he acts as the interview moderator (HMM) for the recorded focus group.

The DVD presentation starts with some introductory comments made by a female narrator who is not a participant in the interview, and that were not filmed at the same setting where we see the HMM with the participants. This suggests that the introductory narrative may have been filmed towards the end of production. In any case, it could be said that what her comments cover would be important as Hugh Mehan (1979) discovered the orientation remarks of teachers before a lesson tell much about relationships, categories, and any other issues mentioned. Although they are important in terms of seeing how the whole DVD presentation works for whom it was intended (and others), I will focus my analysis on the second part of the DVD presentation, the focus group interview.

The edited interview itself lasts about 20 minutes. Within the structure of the presentation, the appreciation of the expertise of the interviewees relies on the standardized relational pair (SRP) of interviewer - interviewee. Sacks (in McHoul \& Rapley, 2002) defined the rules of a device that helps understand how these two categories work together:

An "omni-relevant device" is one that is relevant to a setting via the fact that there are some activities that are known to get done in that setting, that have no special slot in it, i.e., do not follow any given last occurrence, but when they are appropriate, they have priority. Where, further, it is the business of, say, some single person located via the "omni-relevant device," to do that, and the business of others located via that device, to let it get done (p. 75).

As such, this device establishes certain incumbencies for each of the categories of the interviewerinterviewee pair to actually work. That is, first the two categories are linked because one invokes the other, and secondly, it is incumbent upon the interviewer to ask the interviewees to take on a category such as that of being a 'high school to college student transition expert', not the other way around. Therefore, given the structure of the DVD presentation and the omni-relevant interviewer + interviewee device that is central to how the presentation works, it is helpful to establish at least three broad categories under which to group the analysis of the institutional representatives' and the students' contributions on the DVD. The narrator categories correspond to those invoked by the Hispanic female narrator (HFN) in the introduction. Those invoked by the Hispanic male moderator (HMM) fall under the rubric of interviewer categories, leaving a third umbrella of interviewee categories. 
In order to focus on the interviewee categories, I will need to describe the talk of my consultant, as the interview moderator (HMM) for the DVD who does the business of interviewing. In this sense, it would be incumbent on him to present some sort of interview schedule, and one that covers topics that have to do with the college life experience of his participants as FGCSs. He begins that intervention by saying:

HMM: we're going to be talking today about first generation students and ah you know we come from different cultures different family backgrounds but we also have one culture in in ah common and that is that we're all first generation students? (Extract 3 , Transcript: DVD Presentation).

He brings relevance to the social category of FGCS here, and goes further. Through his discourse of difference, he claims the category of FGCS for himself and spreads it out onto the other participants in terms of "one culture" held in common. I have limited myself here to the use of the Jefferson transcription convention question mark to give the reader a sense of the extent of the details that are studied within the Conversational Analysis ethnomethodological tradition to which MCA pertains (CA and MCA are considered cousins, to freely borrow a family device to contextualize their relationship). The "?" indicates that the HMM makes an upward tone modulation of his voice at the end of the extract, a point that would be relevant for an analysis objective that wants to explore interview talk and which in this case would indicate that the upward modulation used in questions can also function as way to initiate a turn, a task that is completely congruent with the interviewer + interviewee omni-relevant device. Also congruent with this device is that the participants allow the HMM to "do" his interview schedule of specific topics: a) how they decided to attend college, b) if they felt academically prepared, c) what they thought of their dormitory experience, d) what resources they used to stay on top of their studies, e) how different the college experience was for them, f) what organizations or events they attended, g) how they handled the financial pressures of going to college, and $h$ ) what their experiences were with mentors. The HMM also focuses on the general impressions the participants had with respect to their "going back home" experiences, and inquires into where they found the strength to continue in school despite sometimes feeling like quitting. In the last segment of the edited DVD presentation, the moderator asks the participants to act as 'students who made an effective transition to college' experts. He asks them to address the DVD 'viewers' as persons who might have doubts about going to college.

The different sequences could be easily plotted onto the sections of an FGCS literature review. I have chosen to draw attention to the talk of an Hispanic woman (HF1) in Extract 4, her response to the HMM's question that initiates the FGCS-persistence sequence, because of how this topic resonates with many of the characteristics that I alluded to earlier of persons acted upon in higher education to assure their academic success.

HMM: I mean I know that you feel like quitting at times and things are going well but something kept you here you're still here. where does that come from? where does that strength come from?

HF1: I think, just the fact of knowing that you're getting an opportunity to get an education cuz there's like a lot of people out there that wish they could but they can't, I mean look at the third world country, you know a lot of kids over there want to go to college but they can't.

HMM:uh hum. 
HF1: they're deprived from that and if you think about it, to them we have it so easy, it's like, it's your decision you can go if you really want to, everything is out there it's for just you to do it. (Extract 4, Transcript: DVD Presentation).

A detailed analysis would unpack all of the categories that imbue this interaction with meaning. In terms of glocal practice, the difference discourse of the introduction has morphed into one of distance. Although this woman may or may not have had first-hand experience in a "third world country", there are at least three categories that have gained purchase: 'FCGS', 'Hispanic', and 'FG'. Taken separately, all three of them are difference categories but when they get organized together they take on another characteristic that has to do with distance. The introduction of the first generation category (FG, as immigrant or in this case a possible immigrant student) hovers there without any explicit explanation. The HF1 does not say that she herself is from a "third world country", yet if we see her performance in terms of the DVD's intended 'viewers', we see evidence of a reaching out to them in this educational marketing tool that presents the experiences of a group of First Generation College Students. This is similar to the way the HMM started the interview, where he talks about difference in order to prioritize the participants' performance as FGCSs and then establishes a personal contact with them when he says, "we also have one culture in in ah common and that is that we're all first generation students?"

\section{Discussion}

Nearness and remoteness, as characteristics of categories found in the talk and text of the extracts presented here are evidence of institutional glocal practice, of things done in terms of a bridging identity work that traces a direction towards a future that could be considered foreign or out of reach. University policies in action, in promotion, commemorative, and introductory settings are evidence of the practices of persons in higher education. The hospitality work of the interaction in the hallway, and the rationale in the FGCS-persistence sequence that appeals to a category of people who pertain to a distant place are evidence of the movement required to begin to belong in higher education. The ethnography from which this data comes was also able to identify practices directed at sustaining this often tenuous connection for first generation college students (and others) all the way through to a graduation ceremony.

University policies directed at FGCSs in my fieldwork may be similar to those of the Widening Participation initiatives in the UK, as institutions sitting and waiting in varying degrees for individuals in the marketplace to participate in higher education. However, despite banal debates about linking student body diversification with social justice, there is evidence that just as higher education policies in action breathe the fumes of economic redistribution, they also bask in the aroma of identity claims for recognition. Framed as practices with global impact through gestures of local contact, we might begin to appreciate them for how these kinds of projects are inviting us to reach out across distances, short and long.

\section{References}

Alvarado, José Gerardo (2010). University Policies in Action: 'Identity Work' and First Generation College Students. Unpublished Ph.D. dissertation, Universitat Autònoma de Barcelona. 
Alvarado, José Gerardo \& İ̃iguez-Rueda, Lupicinio (2009). Ethnography as a social science perspective: a review. Psico, 40(1), 7-16. Retrieved September 20, 2009 from http://revistaseletronicas.pucrs.br/fass/ojs/index.php/revistapsico/article/view/5422/4136

Amelink, Catherine T. (2005). Predicting academic success among first-year, first generation students. Unpublished Ph.D. dissertation, Virginia Polytechnic Institute and State University.

Anderson, James A. (1995). Toward a framework for matching teaching and learning styles for diverse populations. In Ronald R. Sims \& Serbrenia J. Sims (Eds.), The importance of learning styles: Understanding the implications for learning, course design, and education (pp. 68-98). Westport, CT: Greenwood Press.

Antaki, Charles (1998). Identity as an achievement and as a tool. In Charles Antaki \& Sue Widdicombe (Eds.), Identities in Talk (pp. 1-14). London: SAGE Publications.

Brubaker, Rogers (2009). Ethnicity, race, and nationalism. Annual Review of Sociology, 35(1), 21-42. doi:10.1146/annurev-soc-070308-115916.

Brubaker, Rogers \& Cooper, Frederick (2002). Beyond "identity". Theory and Society, 29, 1-47.

Choy, Susan P. (2001). Students whose parents did not go to college: Postsecondary access, persistence, and attainment. (NCES 2001-126) U.S. Department of Education. Washington, DC: National Center for Education Statistics.

D'Amico, Mark M. (2004). The academic performance and retention of first-generation college students at a four-year state-supported university. Unpublished Ph.D. dissertation, The University of North Carolina at Greensboro.

David, Miriam E. (2009). Diversity, gender and widening participation in global higher education: a feminist perspective. International Studies in Sociology of Education, 19(1), 1-17. doi:10.1080/09620210903057590.

Deil-Amen, Regina \& López Turley, Ruth N. (2007). A review of the transition to college literature in sociology. Teachers College Record, 109(10), 2324-2366. Retrieved March 5, 2007 from http://www.tcrecord.org/content.asp?contentid=12583

Espanola, Mirasol Caronongan (2004). First-generation college students: Academic preparation, academic involvement and retention. Unpublished Ed.D. dissertation, University of Southern California.

Fraser, Nancy \& Honneth, Axel (2003). Redistribution or recognition? A political-philosophical exchange. London: Verso.

Freiberg, Jill \& Freebody, Peter (2009). Applying membership categorisation analysis to discourse: When the 'tripwire critique' is not enough. In Thao Lê, Megan Short, \& Quỳnh Lê (Eds.), Critical discourse analysis: An interdisciplinary perspective (pp. 49-64). Hauppage, NY: Nova Science Publishers. 
Gulikers, Goedele; Meredith, Massey \& Swartz, Brenan (2004). Standardizing generation 1.5 programs in Maryland. Retrieved $\quad$ February 27, 2007, from http://academic.pgcc.edu/instruction/if/if_19_03/gulikers-massey-swartz-3-04.pdf

Hansen, Alan D. (2005). A practical task: Ethnicity as a resource in social interaction. Research on Language \& Social Interaction, 38(1), 63-104.

Hayes, William Donald (1999). A naturalistic investigation of first-generation college graduates: From alienation to empowerment. Ed.D. dissertation, Northern Illinois University.

Hester, Stephen, \& Eglin, Peter. (1997). Membership categorization analysis: an introduction. In Stephen Hester \& Peter Eglin (Eds.), Culture in action: studies in membership categorization analysis (pp. 1-24). Washington, D.C: International Institute for Ethnomethodology and Conversation Analysis \& University Press of America.

Jean, Daniel (2010). The academic and social adjustments of first generation college students. Unpublished Ed.D. dissertation, Seton Hall University.

Joyce, Beverly Ann (1987). "First generation" college students: A study of college choice. Unpublished Ph.D. dissertation, Boston College.

Kuriloff, Peter \& Reichert, Michael C. (2003). Boys of class, boys of color: Negotiating the academic and social geography of an elite independent school. Journal of Social Issues, 59(4), 751-769.

Kurotsuchi Inkelas, Karen; Daver, Zaneeta E.; Vogt, Kristen E. \& Brown Leonard, Jeannie (2007). Livinglearning programs and first-generation college students' academic and social transition to college. Research in Higher Education, 48(4). doi:10.1007/s11162-006-9031-6.

Lederman, Doug (2005). Debating Equity and Excellence. Retrieved February 21, 2007 from http://www.insidehighered.com/news/2005/05/02/equity

Lee, Wynetta Y. (2004). Transforming the first-year of experience of African Americans. In Laura I. Rendón, Mildred García \& Dawn Person (Eds.), Transforming the first-year experience for students of color (Vol. 38) (pp. 93-107). Columbia, SC: University of South Carolina, National Resource Center for The First-Year Experience and Students in Transition.

McHoul, Alec \& Rapley, Mark (2002). "Should we make a start then?": A strange case of (delayed) clientinitiated psychological assessment. Research on Language and Social Interaction, 33(1), 73-91.

Mehan, Hugh (1979). Learning lessons: Social organization in the classroom. Cambridge: Harvard University Press.

Murphy, Catrina G. (2006). Differences in academic and social expectations of first-generation and nonfirst-generation undergraduates at a historically black university. Unpublished Ph.D. dissertation, University of Virginia.

Nolan, Ronnie (2005). First-generation college graduates: An examination of the relationship between the barriers to graduation and the motivating factors. Unpublished Ed.D. dissertation, North Carolina State University. 
Sarroub, Loukia K. (2008). Living "glocally" with literacy success in the Midwest. Theory Into Practice, 47(1), 59-66. doi:10.1080/00405840701764789.

Scott, Bradley (1996). A different kind of will: Education equity and the school reform movement. $\begin{array}{llll}\text { Retrieved } \quad \text { August } & 10, & \text { from }\end{array}$ http://www.idra.org/IDRA_Newsletter/January_1997_School_Organization/A_Different_Kind_of_ Willl

Simmel, Georg (1950). The stranger. In Kurt Wolff \& Georg Simmel (Ed.), The sociology of Georg Simmel (pp. 402-408). New York: Free Press.

Stanfield, John H. (1993). A history of race relations research: First-generation recollections. Newbury Park, CA: Sage.

Stevenson, Jacqueline; Clegg, Sue \& Lefever, Ruth (2010). The discourse of widening participation and its critics: an institutional case study. London Review of Education, 8(2), 105-115. doi:10.1080/14748460.2010.487328.

Suárez-Orozco, Marcelo M. (2001). Globalization, immigration, and education: The research agenda. Harvard Educational Review, 71(3), 345-366.

Suggs, Welch (2005). A place on the team: The triumph and tragedy of Title IX. Princeton, N.J: Princeton University Press.

Thomas, Liz \& Quinn, Joyce (2006). First generation entry into higher education: An international study. Maidenhead, England: Society for Research into Higher Education and Open University Press.

USGPO (2000). Attracting a new generation to math and science: The role of public-private partnerships in education and H.R. 1265, the Mathematics and Science Proficiency Partnership Act: Hearing before the Subcommittee on Basic Research of the Committee on Science, House of Representatives, One Hundred Sixth Congress, first session, July 29, 1999. Retrieved $\begin{array}{llll}\text { December } & 22, & 2008 & \text { from }\end{array}$ http://commdocs.house.gov/committees/science/hsy210140.000/hsy210140_0f.htm

VanFossen, Michael L. (2005). A family affair: A study regarding the impact of parental involvement on the personal development of traditional first-year college students. Unpublished Ph.D. dissertation, Saint Louis University.

Warburton, Edward C; Bugarin, Rosio \& Nuñez, Anne-Marie (2001). Bridging the gap: Academic preparation and postsecondary success of first-generation students (NCES 2001-153). Retrieved February 21, 2007 from The NCES World Wide Web site http://nces.ed.gov/pubs2001/2001153.pdf

\section{Citation format}

Alvarado, José Gerardo (2012). Higher Education Student Body Diversification as Glocal Practice. Athenea Digital, 12(2), 221-234. Disponible en http://psicologiasocial.uab.es/athenea/index.php/atheneaDigital/article/view/Alvarado 


Este texto está protegido por una licencia Creative Commons.
Usted es libre de copiar, distribuir y comunicar públicamente la obra bajo las siguientes condiciones:
Reconocimiento: Debe reconocer y citar al autor original.
No comercial. No puede utilizar esta obra para fines comerciales.
Sin obras derivadas. No se puede alterar, transformar, o generar una obra derivada a partir de esta obra.
\[ \underline{\text { Resumen de licencia - Texto completo de la licencia }} \]

